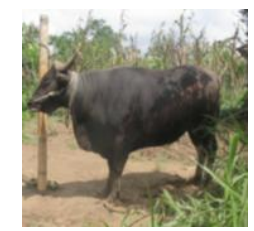

Journal FADET UNUD

\title{
PRODUKSI KARKAS AYAM PERSILANGAN WHITE GOLD X LANCY YANG DIBERI JUS KULIT BUAH NAGA (Hylocereus sp) PADA AIR MINUM
}

\author{
Anestika, N. P. P., G. A. M. K. Dewi, I W. Wijana \\ P.S. Peternakan, Fakultas Peternakan, Universitas Udayana, JL. P.B. Sudirman, Denpasar \\ E - mail : Putrianestika@student.unud.ac.id ,Telp: 087752530608
}

\begin{abstract}
ABSTRAK
Studi ini bertujuan untuk mengkaji bobot dan potongan karkas ayam kampung persilangan White Gold X Lancy yang diberi jus kulit buah naga melalui air minum. Telah dilaksanakan di kandang milik peternak yang berlokasi di Jalan Cekomaria, Peguyangan, Banjar Kedua, Denpasar. Selama 8 minggu. Penelitian dilaksanakan dengan menggunakan Rancangan Acak Lengkap (RAL) yang terdiri dari empat perlakuan, yaitu: R0: Tanpa pemberian jus kulit buah naga melalui air minum, R1: Penambahan 5\% jus kulit buah naga melalui air minum, R2: Penambahan $10 \%$ jus kulit buah naga melalui air minum dan R3: Penambahan $15 \%$ jus kulit buah naga melalui air minum. Variabel yang diamati adalah bobot potong, bobot karkas, persentase karkas, bobot dada, paha, sayap, dan punggung. Hasil penelitian menunjukan bahwa pemberian perlakuan R1, R2 dan R3 masing - masing 5,64\%, $8,20 \%$ dan $8,87 \%$ lebih tinggi $(\mathrm{P}<0,05)$ dari pada R0 (kontrol). Sedangkan perlakuan $\mathrm{R} 1$ $2,77 \%$ lebih rendah dari R2 ( $>>0,05)$ pada bobot dada. Berdasarkan hasil penelitian dapat disimpulkan bahwa pemberian jus kulit buah naga sebanyak 5\%, 10\% dan 15\% berpengaruh terhadap bobot dada, paha dan persentase karkas, tetapi tidak berpengaruh terhadap bobot potong, bobot karkas,sayap dan punggung ayam persilangan White Gold X Lancy umur 14 minggu.
\end{abstract}

Kata kunci: jus kulit buah naga, karkas, recahan karkas, ayam persilangan

\section{CARCASSES PRODUCTION OF WHITE GOLD CROSSBRED CHIKEN WITH LANCY FEED DRAGON FRUIT PEEL JUICE (Hylocereus sp) THROUGHT DRINKING WATER}

\begin{abstract}
This study aims to examine the weight and cut carcasses of White Gold X Lancy crossbreed chickens fed dragon fruit skin juice through drinking water. Has been carried out in a breeder's cage located on Jalan Cekomaria, Peguyangan, Banjar Kedua, Denpasar. For 8 weeks. The study was carried out using a Completely Randomized Design (CRD) consisting of four treatments, namely: R0: Without administration of dragon fruit skin juice through drinking water, R1: Addition of 5\% dragon fruit skin juice through drinking water, R2: Addition of $10 \%$ skin juice dragon fruit through drinking water and R3: Addition of $15 \%$
\end{abstract}


dragon fruit skin juice through drinking water. The observed variables were cutting weight, carcass weight, carcass percentage, chest weight, thigh, wing, and back. The results showed that the treatment of R1, R2 and R3 were $5.64 \%, 8.20 \%$ and $8.87 \%$ respectively $(\mathrm{P}<0.05)$ than R0 (control). Whereas the R1 treatment was $2.77 \%$ lower than R2 (P>0.05) in chest weight. Based on the results of the study it can be concluded that the administration of dragon fruit skin juice as much as 5\%,10\% and $15 \%$ affect the weight of the chest, thighs and percentage of carcass, but it does not affect the cutting weight, carcass weight, wings and back of the chicken crossing White Gold X Lancy age 14 weeks.

Key words: dragon fruit skin juice, carcass, carcass fracture, crossbred chicken

\section{PENDAHULUAN}

\section{Latar Belakang}

Ayam kampung merupakan ayam lokal Indonesia yang kehidupannya sudah lekat dengan masyarakat, juga dikenal dengan sebutan ayam buras (bukan ras) atau ayam sayur yang telah mengalami domestikasi (Dewi et al., 2017). Ayam White Gold X Lancy adalah ayam kampung keturunan dari ayam kancingan yang telah menyebar di Bali. Ayam jenis ini banyak diminati oleh masyarakat penggemar ayam hias dan aduan. Dimana secara ekonomis sangat menguntungkan karena harganya yang lebih mahal berkisar Rp. 100.000 - Rp. 300.000/ekor umur ayam 10 minggu. Dalam usaha mengembangkan ayam kampung masih menghadapi berbagai kendala, antara lain sistem pemeliharaan masih tradisional, produktivitas rendah, baik produksi daging maupun produksi telur, variasi mutu genetik, tingkat kematian tinggi, pemberian pakan sebelum sesuai kebutuhan baik kuantitas maupun kualitasnya (Siregar et al.,1982). Pola pemeliharaan secara intensif dapat memperbaiki produktivitas ayam kampung (Creswell dan Gunawan, 1982). Ayam kampung persilangan White Gold X Lancy pejantan yang sudah dewasa mempunyai bobot badan berkisar antara 2$2,5 \mathrm{~kg}$, sementara betina sekitar 1,5 kg. Berat ringannya bobot badan dipengaruhi oleh tebal tipisnya daging (perototan) dan pertulangan. semakin tebal otot dan semakin besar tulang tulang yang dimiliki ayam kampung persilangan White Gold X Lancy, maka semakin berat pula bobot badannya (Chandra, 2014). Menurut Rasyaf (2004) faktor - faktor yang mempengaruhi pertumbuhan ayam yakni : ransum, genetik, lingkungan dan pemeliharaan. Agar ayam kampung pertumbuhan cepat maka dapat dipelihara dengan menggunakan sistem umbaran (freerange).

Penampilan ayam kampung sangat beragam, begitu pula sifat genetiknya, penyebarannya sangat luas karena populasi ayam buras dijumpai di kota maupun di desa. Bagi pencinta ayam bisa mengerti kualitas ayam ini dan bagaimana cara pemeliharaan atau 
managemennya agar ayam sehat. Lebih baik lagi, alasnya tanah sehingga ayam bebas berkeliaran dan dalam kandang tersebut dibuatkan tempat bertengker ayam dari kayu atau bambu, karena ayam suka lompat, loncat dan bertengker, ini akan melatih otot ayam sehingga relatif kekar (Bakrie et al.,2003).

Masalah utama dalam pengembangan ayam kampung adalah rendahnya produktivitas, jumlah pakan yang diberikan belum mencukupi dan pemberian pakan yang belum mengacu kepada kaidah ilmu nutrisi (Gunawan, 2002 dan Zakaria, 2004a). Terutama pemberian pakan yang belum memperhitungkan kebutuhan zat-zat makanan untuk berbagai tingkat produksi. Keadaan tersebut disebabkan karena belum cukupnya informasi mengenai kebutuhan nutrisi untuk ayam kampung. Peningkatan populasi, produksi dan efisiensi usaha ayam kampung perlu ditingkatkan dari tradisional ke arah agribisnis (Zakaria, 2004b). Kebutuhan gizi untuk ayam paling tinggi selama minggu awal (0-8 minggu) dari kehidupan, oleh karena itu perlu diberikan ransum yang cukup mengandung energi, protein, mineral, dan vitamin dalam jumlah yang seimbang. Faktor lainnya adalah perbaikan genetik ayam kampung yang harus didukung dengan perbaikan nutrisi pakan (Setioko dan Iskandar, 2005). Sampai saat ini standar gizi ransum ayam kampung yang dipakai di Indonesia didasarkan rekomendasi Scott et al. (1982). Menurut Scott et al. (1982) kebutuhan energi termetabolis ayam tipe ringan umur2-8 minggu antara $1600-3100 \mathrm{kkal} / \mathrm{kg}$ dan protein $18 \%-21,4 \%$. Proporsi tulang, otot dan lemak sebagai komponen utama karkas, dipengaruhi oleh umur, jenis kelamin, temperatur, kelembaban dan nutrisi (Soeparno, 1992), lebih lanjut kualitas karkas dipengaruhi oleh faktor genetik, jenis hewan, bangsa, tipe ternak, jenis kelamin, umur, pakan ternak,termasuk pakan aditif, dan stress yang dipengaruhi oleh faktor lingkungan. Ayam kampung diberikan pakan komersial efisiensi penggunaan pakan lebih rendah dibandingkan ayam broiler, untuk meningkatkan efisiensi penggunaan pakan ayam kampung perlu diberikan senyawa atau penambahan nutrisi antioksidan. Antioksidan banyak terkandung didalam kulit buah naga.

Kulit buah naga adalah salah satu bahan limbah dari proses pengupasan buah naga untuk konsumsi masyarakat, banyak tersedia dapat digunakan sebagai pakan alternatif. Pemasok buah naga di Pulau Bali berasal dari Jawa Timur, Jakarta dan seluruh daerah Bali. Produksi buah naga secara nasional pada tahun 2012 mencapai 6.696 ton (Santoso, 2013). Menurut Citramukti (2008) bahwa bagian dari buah naga $65-70 \%$ adalah buahnya dan 30$35 \%$ merupakan kulit. Selanjutnya dari $100 \mathrm{~g}$ buah naga mengandung 60 kalori yakni 18 kalori dari lemak, 8 kalori dari protein dan 34 kalori dari karbohidrat dan mengandung air 
sebesar 90,20\%. Kulit buah naga mengandung vitamin C, vitamin E, vitamin A, alkaloid, terpenid, flavonoid, tinamin, niasin, piridoksin, kobalamin, fenolik, karoten, dan fitoalbumin yang diduga juga memiliki manfaat sebagai antioksidan (Jaafar et al., 2009). Menurut Wu et $a l .$, (2006), keunggulandari kulit buah naga yaitu merupakan sumber antioksidan. Selain itu aktivitas antioksidan pada kulit buah naga lebih besar dibandingkan aktivitas pada daging buahnya, sehingga berpotensi untuk dikembangkan menjadi sumber antioksidan alami. Maka pemberian jus kulit buah naga dalam air minum sangat baik diberikan untuk meningkatkan produksi karkas pada ayam persilangan White Gold X Lancy.

Hasil penelitian (Dewi et al.,2016) penggunaan jus kulit buah naga terfermentasi sampai level 9\% pada ayam kampung dapat meningkatkan produktivitas, karkas yang lebih baik serta FCR yang lebih rendah dibandingkan tanpa mendapat jus kulit buahnaga.

\section{MATERI DAN METODE}

\section{Tempat dan waktu penelitian}

Penelitian ini dilaksanakan di kandang ayam milik peternak, yang berlokasi Jalan Cekomaria, Peguyangan, Banjar Kedua, Denpasar ,selama 8 minggu.

\section{Ayam persilangan White Gold X Lancy}

Ayam yang digunakan adalah ayam persilangan White Gold X Lancy yang berumur 6

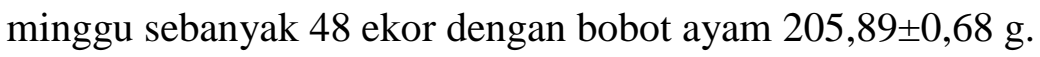

\section{Kandang dan perlengkapan}

Kandang yang digunakan berukuran $90 \mathrm{~cm}$ x $90 \mathrm{~cm}$ dan tingginya $100 \mathrm{~cm}$ sebanyak 16 petak. Setiap petak kandang akan berisi masing - masing 3 ekor ayam. Setiap kandang dilengkapi dengan tempat pakan dan tempat air minum plastik.

\section{Ransum yang diberikan}

Ransum yang diberikan adalah ransum komersial CP511 PT Charoen Pokhpand Indonesia, yang memilik kandungan nutrisi sebagai berikut :

Tabel 1 Kandungan Nutrisi CP511 PT.Charoen Pokhpand Indonesia

\begin{tabular}{ll}
\hline Kandungan Nutrisi & Jumlah Nutrisi \\
\hline EM (kkal/kg) & 3448 \\
Protein (\%) & 23,0 \\
Lemak (\%) & 5,0 \\
Serat (\%) & 5,0 \\
Abu (\%) & 7,0 \\
Kalsium (\%) & 0,9 \\
Phospor (\%) & 0,6 \\
\hline
\end{tabular}


Keterangan : Label kandungan pakan CP511 PT. Charoen Pokhpand Indonesia

\section{Peralatan}

Peralatan yang digunakan berupa kantong plastik tempat ransum, timbangan digital kapasitas $5 \mathrm{~kg}$ dengan kepekaan 0,1 g untuk menimbang pakan dan ayam, ember untuk tempat mencampur jus kulit buah naga dengan air, gelas ukur untuk mengukur air minum, blender untuk membuat jus kulit buah naga, saringan untuk menyaring jus kulit buah naga agar tidak banyak ampasnya, alat tulis yang diperlukan untuk pencatatan data.

\section{Rancangan penelitian}

Metode yang digunakan Rancangan Acak Lengkap (RAL) yang terdiri dari 4 perlakuandan 4 ulangan dan setiap ulangan terdiri dari 3 ekor ayam persilangan, total ayam yang digunakan sebanyak 48 ekor. Perlakuan air minum yang diberikan adalah: R0 : tanpa jus kulit buah naga (Hylocereus sp), R1: 5\% jus kulit buah naga (Hylocereus sp), R2: 10\%jus kulit buah naga (Hylocereus sp) dan R3: 15\%jus kulit buah naga (Hylocereus sp) yang diberikan melalui air minum. Air minum diberikan secara ad libitum dan semua perlakuan diberikan ransum komersial dengan jumlah dan kandungan yang sama.

\section{Pembuatan jus kulit buah naga}

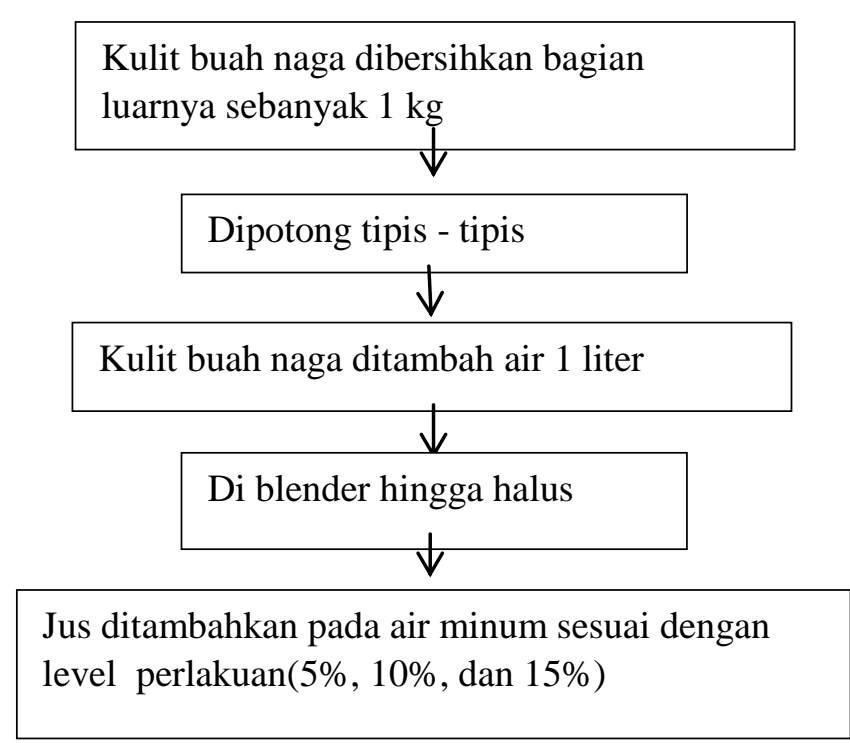

Gambar lcara pembuatan jus kulit buah naga (Hylocereus sp)

\section{Pemberian ransum dan air minum}

Pemberian ransum diberikan 2 kali sehari. Pemberian ransum dilakukan dengan menempatkan tempat pakan ayam dalam kandang pada setiap perlakuan. Pemberian air 
minum secara ad libitum, mengganti air minum setiap hari, hal ini dilakukan agar air minum pada ayam tetap bersih dan layak diminum untuk ayam.

\section{Variabel yang diamati}

Variabel yang diamati dalam penelitian ini:

a. Bobot potong diperoleh dari menimbang bobot hidup berumur 14 minggu, setelah dipuasakan selama $12 \mathrm{jam}$.

b. Bobot Karkas diperoleh dari menimbang total bobot potong - bobot darah, bobot bulu, kepala, leher, dan kaki, serta organ dalam (jantung, limfa, saluran pencernaan dan hati) (USDA,1977).

c. Persentase karkas diperoleh dari hasil bagi antara bobot karkas dengan bobot potong dikalikan $100 \%$.

d. Bobot potongan komersial

- Bobot potongan dada diperoleh dengan menimbang bagian dada yang dipotong sepanjang pertautan antara tulang rusuk yang melekat pada punggung dengan tulang rusuk yang melekat pada dada sampai sendibahu.

- Bobot potongan punggung diperoleh dengan menimbang bagian punggungsetelah dipisahkan dari bagian dada, paha dansayap.

- Bobot potongan paha diperoleh dengan menimbang bagian paha yang dipotong pada sendi Articulation coxae dengan Oshumerus.

- Bobot potongan sayap diperoleh dengan menimbang bagian sayap yang dipotong pada pangkal persendian Oshumerus

\section{Analisis data}

Data yang terkumpul dianalisis dengan sidik ragam, apabila diantara perlakuan ada perbedaan yang nyata $(\mathrm{P}<0,05)$ dilanjutkan dengan uji jarak berganda Duncan, (Steel dan Torrie, 1990).

\section{HASIL DAN PEMBAHASAN}

Data dari hasil penelitian yang diperoleh (Tabel 2) menunjukkan bahwa secara statistic, penambahan jus kulit buah naga (Hylocereus sp) sebesar 5\%, 10\% dan 15\% memberikan pengaruh nyata terhadap persentase karkas, bobot dada, dan bobot paha. 
Tabel 2 Pengaruh pemberian jus kulit buah naga (Hylocereus sp) melalui air minum terhadap karkas dan potongan bobot karkas ayam White Gold $X$ Lancy.

\begin{tabular}{lllllc}
\hline \multirow{2}{*}{ Variabel } & \multicolumn{4}{c}{ Perlakuan } & Sem \\
\cline { 2 - 5 } & R0 & R1 & R2 & R3 & \\
\hline Bobot Potong (g) & $710,25^{\mathrm{a}}$ & $710,33^{\mathrm{a}}$ & $710,40^{\mathrm{a}}$ & $710,48^{\mathrm{a}}$ & 0,18 \\
Bobot Karkas (g) & $379,43^{\mathrm{a}}$ & $389,50^{\mathrm{a}}$ & $394,53^{\mathrm{a}}$ & $395,23^{\mathrm{a}}$ & 8,19 \\
Persentase Karkas \%) & $52,38^{\mathrm{a}}$ & $53,78^{\mathrm{b}}$ & $54,42^{\mathrm{c}}$ & $54,52^{\mathrm{c}}$ & 0,14 \\
Potongan Bobot Karkas : & & & & & \\
Bobot Dada (g) & $98,47^{\mathrm{a}}$ & $104,36^{\mathrm{b}}$ & $107,26^{\mathrm{b}}$ & $108,06^{\mathrm{b}}$ & 0,55 \\
Bobot Punggung(g) & $96 ., 43^{\mathrm{a}}$ & $94,70^{\mathrm{a}}$ & $95,94^{\mathrm{a}}$ & $96,42^{\mathrm{a}}$ & 53,90 \\
Bobot Sayap (g) & $74.29^{\mathrm{a}}$ & $71,90^{\mathrm{a}}$ & $73,41^{\mathrm{a}}$ & $73,68^{\mathrm{a}}$ & 7,29 \\
\hline Bobot Paha (g) & $110,24^{\mathrm{a}}$ & $118,54^{\mathrm{b}}$ & $117,93^{\mathrm{b}}$ & $117,08^{\mathrm{b}}$ & 0,84 \\
\hline
\end{tabular}

Keterangan :

1. R0 : Ayam diberikan air minum tanpa jus kulit buah naga

$\mathrm{R} 1$ : Ayam diberikan air minum dengan $5 \%$ jus kulit buahnaga

R2 : Ayam diberikan air minum dengan $10 \%$ jus kulit buah naga

R3 : Ayam diberikan air minum dengan $15 \%$ jus kulit buah naga

2. SEM : "Standard Error of The TreatmentMeans"

3. Superskrip yang sama pada baris yang sama menunjukan perbedaan yang tidak nyata $(\mathrm{P}>0,05)$

Hasil penelitian pemberian jus kulit buah naga dalam air minum menunjukkan bahwa bobot potong dengan penambahan jus kulit buah naga pada perlakuan R3 dengan bobot potong perlakuan R2, R1 dan R0 memiliki hasil yang relatif sama (Tabel 2). Namun secara kuantitatif bobot potong pada perlakuan R3 lebih rendah dari R0 dan secara statistik berbeda tidak nyata $(\mathrm{P}>0,05)$. Ayam kampung yang diberikan perlakuan $\mathrm{R} 2$ dan $\mathrm{R} 1$ secara kuantitatif lebih rendah dari pada perlakuan R3 meskipun tidak nyata (Nugraha et al., 2018). Hal ini disebabkan karena kulit buah naga mengandung antosianin yang berperan sebagai antioksidan. Ayam persilangan White Gold X Lancy yang diberikan penambahan jus kulit buah naga dalam air minumnya akan membantu dalam proses pencernaan dan dapat berfungsi sebagai probiotik pada ayam sehingga zat-zat makanan dapat diserap dengan baik. Hal ini sesuai dengan pendapat Jin et al,. (1997) yang menyatakan bahwa keberadaan probiotik atau mikroba menguntungkan dalam saluran pencernaan dapat meningkatkan aktivitas enzim dan meningkatkan kecernaan pada ayam.

Hasil penelitian menunjukkan bahwa bobot karkas pada ayam persilangan White Gold $X$ Lancy yang diberikan jus kulit buah naga dalam air minum pada perlakuan R3 memiliki bobot karkas yang paling tinggi, namun secara statistik berbeda tidak nyata $(\mathrm{P}>0,05)$ dengan perlakuan R0, R1 dan R2 (Tabel 2). Hasil tersebut menunjukkan bahwa pemberian jus kulit 
buah naga dalam air minum belum dapat mempengaruhi bobot karkas ayam persilangan White Gold X Lancy, karena faktor yang paling mempengaruhi bobot karkas adalah bobot potong. Hal ini sesuai dengan pendapat Herman (1989) menyatakan bahwa berat karkas pada ayam dipengaruhi oleh bobot potong sehingga semakin tinggi bobot potong maka bobot karkas yang dihasilkan juga semakin tinggi. Selain itu faktor genetik dan lingkungan dapat mempengaruhi laju pertumbuhan dan komposisi tubuh yang meliputi distribusi bobot dan komponen karkas.

Berdasarkan persentase karkas pada perlakuan R3 dengan bobot potong yang relatif sama menghasilkan persentase karkas yang paling tinggi dan secara statistik berbeda nyata $(\mathrm{P}<0,05)$ dengan perlakuan R0, R1 dan R2 (Tabel 2). Hal ini disebabkan karena adanya kandungan senyawa antioksidan pada kulit buah naga yang dapat meningkatkan efisiensi penggunaan zat makanan, khususnya protein, sehingga meningkatkan persentase karkas. Selain itu, senyawa antioksidan tersebut dapat menghambat pertumbuhan mikroorganisme yang merugikan dalam saluran pencernaan ayam, sehingga pemanfaatan zat makanan oleh ayam dapat optimal (Setiyawan et al., 2014). Sehingga penyerapan nutrisi akan lebih baik dan nutrisi lebih banyak disimpan dalam daging ayam. Hasil penelitian ini sesuai dengan Mustika et al. (2014) menyatakan kandungan yang terdapat dalam kulit buah naga merah dapat berfungsi sebagai antibakteri sehingga penyerapan zat makanan lebih optimal. Selain itu, disebakan karena air minum yang tercampur dengan jus kulit buah naga membuat kebutuhan akan nutrisi harian ayam lebih cepat terpenuhi sehingga ayam lebih memilih air minum jus kulit buahnaga.

Pemberian jus kulit buah naga (Hylocereus $s p$ ) melalui air minum ternyata memberikan pengaruh terhadap bobot potongan karkas komersial bagian dada, namun dari angka yang diperoleh nilai yang lebih tinggi dibandingkan dengan kontrol secara statistik berbeda nyata $(\mathrm{P}<0,05)$. Peningkatan ini disebabkan oleh pemberian jus kulit buah naga yang membantu proses pencernaan ransum sehingga ketersediaan zat - zat makanan menjadi lebih banyak. Kecendrungan peningkatan berat potongan karkas bagian dada merupakan bagian karkas yang banyak mengandung otot jaringan yang perkembangannya lebih dipengaruhi oleh zat makanan khususnya protein (Bahji, 1991). Hal ini berkaitan dengan pernyataan Abubakar dan Nataamijaya (1999) yang menyatakan bahwa bagian dada dan bagian paha berkembang lebih dominan selama pertumbuhan apabila dibandingkan dengan bagian punggung dansayap.

Berat punggung ayam persilangan White Gold X Lancy yang tanpa diberikan jus kulit buah naga R0 (kontrol) memiliki angka lebih rendah dibandingkan dengan yang diberikan jus 
kulit buah naga, namun secara statistik berbeda tidak nyata $(\mathrm{P}>0,05)$ dengan perlakuan $\mathrm{R} 1, \mathrm{R} 2$ dan R3 (Tabel 2) Hal ini disebabkan karena punggung adalah bagian yang didominasi oleh tulang dan kurang berpotensi untuk menghasilkan daging. Hasil penelitian ini sesuai dengan Ilham (2012) yang menyatakan bahwa pada bagian punggung bukan merupakan bagian tempat terjadinya deposisi daging yang utama sehingga pada masa pertumbuhan, nutrien untuk pembentuk daging terdapat pada tempat-tempat deposisi daging. Sedangkan menurut Soeparno (2009) menyatakan bahwa bagian-bagian tubuh yang banyak seperti tulang seperti sayap, kepala, punggung, leher dan kaki, persentasenya semakin menurun dengan meningkatnya.

Penambahan jus kulit buah naga melalui air minum tidak berpengaruh nyata terhadap bobot sayap. Hal ini disebabkan karena sayap didominasi oleh tulang dan kurang berpotensi untuk menghasilkan daging. Soeparno (2009) menyatakan bahwa selama pertumbuhan, tulang tumbuh secara terus-menerus dengan kadarlaju pertumbuhan relatif lambat, sedangkan pertumbuhan otot relatif lebih cepat sehingga rasio otot dengan tulang meningkat selama pertumbuhan dengan kadar laju yang berbeda. Didukung pula oleh Anggraeni (1999)yang menytakan bahwa pertumbuhan sayap sampai 12 minggu pada ayam kampung relatif konstan, sehingga menghasilkan berat sayap yang relatif sama.

Penambahan jus kulit buah naga dalam air minum berpengaruh terhadap bobot paha, dimana angka yang diperoleh R1, R2 dan R3 lebih tinggi dari perlakuan R0 ( kontrol ) dan secara statistik berbeda nyata $(\mathrm{P}<0,05)$. Untuk setiap perlakuan menandakan adanya perbedaan asupan protein serta kemampuan ayam dalam memanfaatkan sebagai antioksidan yang terkandung dalam jus kulit buah naga untuk pertumbuhan jaringan tubuhnya. Menurut Sarjuni dan Mozin (2011) bahwa pemberian jus kulit buah naga melalui air minum mampu meningkatkan bobot badan ayam. Meningkatnya bobot badan ayam akan berpengaruh terhadap karkas lainnya salah satunya pada bagian paha, dan peningkatannya secara signifikan karena bagian paha tersusun atas banyak otot dan daging.

\section{SIMPULAN}

Berdasarkan penelitian dapat disimpulkan bahwa permberian jus kulit buah naga sebanyak 5\%, 10\% dan 15\% berpengaruh terhadap persentase karkas, bobot dada dan bobot paha, tetapi tidak berpengaruh terhadap bobot potong, bobot karkas, bobot sayap, dan bobot punggung ayam persilangan White Gold X Lancy umur 14minggu.

\section{SARAN}


Dari hasil penelitian ini disarankan kepada petani peternak untuk meningkatkan produksi karkas pada ayam persilangan White Gold X Lancy dapat dilakukan dengan menambahkan jus kulit buah naga (Hyolocereus sp) pada air minum.

\section{UCAPAN TERIMAKASIH}

Pada kesempatan ini penulis mengucapkan terimakasih kepada Dekan Fakultas Peternakan Universitas Udayana, dan seluruh pihak yang membantu dalam pelaksanaan hingga penulisan jurnal penelitian ini.

\section{DAFTAR PUSTAKA}

Abubakar dan Nataamijaya. 1999. Persentase karkas dan bagian-bagiannyadua galur ayam broiler dengan penambahan tepung kunyit (Curcuma domestica Val) dalam ransum. Bulletin Peternakan Edisi Tambahan: 174-179.

Anggraeni. 1999. Pertumbuhan Alometri dan Tinjauan Morfologi Serabut Dada (Mucullus pectoralis dan Mucullus supracorarideus) pada Itik dan Entok Lokal. Tesis. Program Pascasarjana Institut Pertanian Bogor, Bogor.

Bahji, A. 1991. Tumbuh kembang potongan karkas komersial ayam broiler akibat penurunan tingkat protein ransum pada minggu ke tiga keempat. Karya ilmiah. Fakultas Peternakan. Institut Pertanian Bogor. Bogor.

Bakrie B, Andayani D, Yanis M, dan Zainuddin D. 2003. Pengaruh penambahan jamu ke dalam air minum terhadap preferensi konsumen dan mutu karkas ayam buras. Seminar Nasional Teknologi Peternakan dan Veteriner. Puslitbang Peternakan

Chandra, 2014. Ilmu Kedokteran Pencegahan Komunis. Jakarta, Erlangga.

Creswell, D. C dan B. Gunawan. 1982. Pertumbuhan badan dan produksi telur dari lima strain ayam sayur pada sistem peternkan intensif. Prosiding Seminar Penelitian Peternakan, Bogor 8 - 11 Februari, Bogor.

Citramukti,Imaniar. 2008. Ekstraksi dan Uji Kualitas Pigmen Antosianin Pada Kulit. Buah Naga Merah (Hylocereus costaricensis), (Kajian Masa Simpan Buah dan Penggunaan Jenis Pelarut), Skripsi, Jurusan THP Universitas. Muhammadiyah Malang.

Dewi, G. A. M. K. 2016. Pemanfaatan Kulit Buah Naga (Hylocereus Sp) Terfermentasi Terhadap Kualitas Daging Dan Kandungan Darah Ayam Broiler .Abstrak Senastek, LPPM-UNUD 
Dewi, G. A. .M. K. 2017. Dewi, G. A. M. K., M. Nuriyasa, dan I W. Wijana. 2017.Effect of diet containing dragon fruit peel meal fermentation for productivity of kampung chickens. The $2^{\text {nd }}$ International Conference on Animal Nutrition and Environment (ANI-NUE). Khon Kaen, Thailand. ISBN 978-616-438-084-4 Vol. II

Gunawan. 2002. Evaluasi Model Pengembangan Usaha Ternak Ayam Buras dan UpayaPerbaikannya. Disertasi, Institut Pertanian Bogor.

Herman. R, 1989.Produksi Kelinci. Fakultas Peternakan IPB, Bogor.

Ilham, M. 2012. Pengaruh Penggunaan Eceng Gondok (Eichornia crassipes) Fermentasi dalam Ransum Terhadap Persentase Karkas, Nonkarkas, dan Lemak Abdominal Itik Jantan Umur Delapan Minggu. Fakultas Pertanian. Universitas Sebelas Maret. Surakarta.

Jaafar, Ali, R., Naszri, M., dan Khairuddin, W., 2009. Proximate analysis of dragon fruit (Hylocereus polyhizus), American Journal of Applied Sciiences, 6 (1) : 1341-1346

Jin, L. R., Y. W. Ho., N. Abdullah and S. Jalaludin. 1997. Probiotics in poultry modes of action. Word's Poultry Science Jurnal V01. 53. Number 4 PP: $351-168$.

Linder, M.C.1985. Biokimia Nutrisi dan Metabolisme.Ed ke-1. Terjemahan. Aminuddin Parakkasi. Universitas Indonesia Press. Jakarta.

Sarjuni, S., dan S. Mozin 2011. Pengaruh Penambahan Tepung Pepaya (caricapapaya L) Dalam Ransum Terhadap Penampilan Ayam Pedaging.

Mustika, A. I. C., O. Sjofjan dan E. Widodo. 2014. Pengaruh Penambahan Tepung Kulit Buah Naga Merah (Hylocereus polyrhyzus) dalam Pakan terhadap Penampilan Produksi Burung Puyuh (Coturnix japonica). (Skripsi). Universitas Brawijaya Malang.

Nugraha, G. A., I. M. Nuriyasa, dan A. W. Puger. 2018 Karkas Ayam Kampung Umur 11 Minggu Yang Diberi Ransum Dengan Tingkat Protein Yang Berbeda. PeternakanTropika Vol. 6 No. 1 Th. 2018: 118 - 128

Santoso, P. J. 2013. Budidaya Buah Naga Organik di Pekarangan, Berdasarkan Pengalaman Petani di kabupaten Malang. Balai Penelitian Tanaman Buah Tropika

Scott, M. L., M. C. Neisheim and R. J. Young. 1982. Nutrition of The Chickens. 2nd Ed. Publishing by : M.L. Scott and Assoc. Ithaca, New York.

Siregar, A. P. M.Sabrani dan Soeprawiro. 1982. Teknik Beternak Ayam Pedaging di Indonesia. Cetakan kedua. Margie Group. Jakarta

Soeparno. 1992. Ilmu dan Teknologi Daging. Gadjah Mada University Press. Yogyakarta

Soeparno. 2009. Ilmu dan Teknologi Daging, Cetakan V. Gadjah Mada University Press. Yogyakarta 
Stintzing, F.C., Scgieber, A. and Carle, R. 2002. Betacyanins in Fruit from Red Purple Pitaya, Hylocereus polyrhizus (Waber) Britton and Rose. Food Chemisty 77: 101-106

Steel, R. G. D. and J. H. Torrie. 1990. Prinsip dan Prosedur Statistik. Suatu Pendekatan Biometrik. Edisi Kedua. Diterjemahkan oleh Bambang Sumantri. Jakarta: PT. Gramedia.

USDA (United State Departement of Agriculture).1977. Poultry Guiding Manual.U. S. Government Printing Office Washington. D.C

Wu, L. C., Hsu, H. W., Chen, Y., Chiu, C. C., and Ho, Y. I., 2006, Antioxidant and Antiproliferative Activities of Red Pitaya, Food Chemistry Volume, 95: 319 - 327

Zakaria, S. 2004a. Pengaruh luas kandang terhadap produksi dan kualitas telur ayam buras yang dipelihara dengan system litter. Bulletin Nutrisi dan Makanan Ternak.5(1): 111.

Zakaria, S. 2004b. Performans ayam buras fase dara yang dipelihara secara intensif dan semi intensif dengan tingkat kepadatan kandang yang berbeda. Bulletin Nutrisi dan Makanan Ternak. 5 (1) : 41-51 